\title{
IMPACT OF PERCEIVED ORGANIZATIONAL SUPPORT ON WORK LIFE BALANCE DURING COVID-19 ERA
}

\author{
Prerana Mishra \\ Research Scholar, ITM University, Gwalior, India \\ Dr. Vandana Bharti
}

Associate Professor \& Dean - School of Management, ITM University, Gwalior, India

\begin{abstract}
This paper studies the concern of the management towards the employees for their well-being and how this all helps the employees to maintain their work life balance especially during the pandemic era. The work stations are established at their own house, it is much complicated for the employees to establish a perfect work life balance within their home, hence the responsibility of the Management also increases towards their employees. Perceived organization support is an important factor for the employee retention, but at the same time now it is also the enhanced responsibility of Management to support the employees in establishing a good work life balance. During this research data of 246 employees from different industries has been collected with an eye to understand the concern of the Organization and its implications on entrenching a strong work life balance for the employees.
\end{abstract}

Key words: Perceived Organizational Support, Work Life Balance, Covid-19 era

Cite this Article: Prerana Mishra and Dr. Vandana Bharti, Impact of Perceived Organizational Support on Work Life Balance during Covid-19 Era, International Journal of Management, 11(12), 2020, pp 1602-1610.

http://iaeme.com/Home/issue/IJM?Volume=11\&Issue=12

\section{INTRODUCTION}

Organizational support increases devotion \& dedication in three ways (Gouldner, 1960). Initially, perceived organizational support creates a sense of accountability with a view towards the organization and employees struggle to accomplish organizational goals across greater commitment and effort (Eisberger et al., 1986; Mawde et al., 1984). Second, organizational support reinforces commitment to meeting the socio-emotional needs of employees and leads to a well-built relationship between employee and company (Eisenberger et al., 1986; Armelli et al., 1998). Third perceived organizational support creates a positive frame of mind resulting in a feeling of support, leading to greater affective commitment 
(Eisenberger et al., 2001). Perceived organizational support mediates the relationship between satisfactory job status and emotional commitment (Stingberg \& Vandenberg, 2003). Thus, many studies have found that organizational support is more important to assessing employee commitment than mentoring and other support. There is a clear difference between perceived organizational support and supervisory support of workers. This means support from the former organization and the latter from the team. Thus, perceived organizational support plays an important role in employer outcomes (Rossi et al., 2015), compared to team support that includes coaching and mentoring.

Perceived organizational support fosters employee feelings. They feel that their company is concerned for them and is trustworthy. Employer and employees benefit collaboratively with perceived organizational support. Employees get good wages and other perks for their diligence and indefatigable work. They acquire superior's support in their work. They are comfortable with the work environment; they feel their work is significant and advantageous to the organization. Perceived Organizational Support, as defined by Dr. Eisenberger, concerns employees' understanding of the extent to which a company's contribution is valued and taken care of by the organization for their prosperity. Percieved organizational support can have implications on the performance of the organizations. Analysts have found that when managers are concerned with their employees' commitment to the company, employees tend to focus on the company's adherence to them. In Weizenberger, Huntington, (Organizational Support Theory, 1986), in social relations, when one person sympathizes with another, it impel the other to reciprocate. There is such a social exchange among employees and employers because the organization is the source of the necessities of the employees and can be termed as the employee-employer relationship.

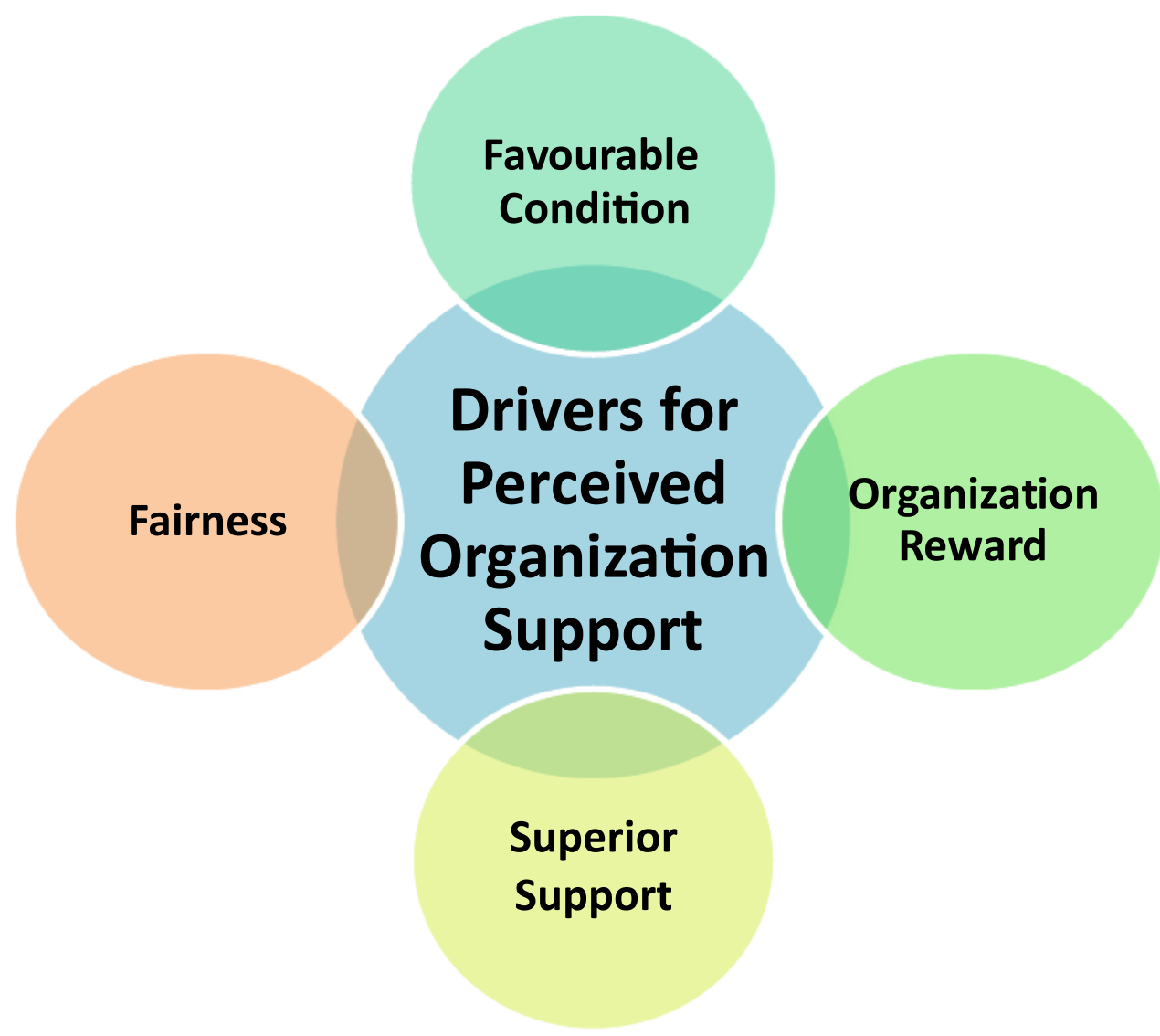

Figure 1 
Organizational support helps the company to produce hard-working employees, who are willing to make any sacrifice for the organization, ready to improve the organization, and they are able to attend to themselves and overcome apathy. Perceived organizational support establishes equality between organizational values and employee values. An organization needs to show greater respect and esteem for the employee and take care of their physiological and psychological needs. This fabricates greater respect among employees towards the company. This automatically creates a full consistency of values. Organizational Support is corelated with the supervisors and managers of an organization. Depending on how their supervisors and managers act, employees often render good quality work to their organizations. Extol, reward and support to an employee will ensure of institutional support. It certainly praises the organization and hard work from the employees, on the contrary it feels that the employee is of no value, no support, and that there is a dwindle in organizational effectiveness.

\section{WORK LIFE BALANCE}

The expression "work life balance" was used to describe the balance between professional work and personal life in the late 1970s. Work-life balance can be defined as "the perfect amalgamation that does not intervene with both work and personal life." According to Julie Morgenstern, "The work life balance is not about the time you work or not work." It is more about how you spend your work and leisure time, and what you do in one to fuel your energy in another. "Work-life balance is a self-defined, self-determined eudaemonia that can be achieved or set as a goal that allows a person to function effectively at home and in the community and manage multiple responsibilities all together. It holds-up physiologically, psychologically, family and health without any anxiety, stress or adverse frame of mind. Two constructs pre-dominate this field of educational investigation: the first is "balance", which is defined as concord or equipoise between work and personal life domains (Clark, Koch, and Hill, 2004; Comer and Strait du, 2006). The other is "conflict" or "hinderance" which is understood as negative or disparity in results of blending paid work and non-paid activities. Work-family conflict has two diverse although relevant concepts: work conflict or family intervention, and family conflict or work intervention (Greenhaus \& Powell, 2006). Work-life conflict is an indispensable part of the entire work-life balance literature and many metaanalyzes provide anecdotes of this structure and explored the repercussion (Byron 2005). Work-life balance portrays the correlation amongst work and personal commitments in an individual's life and the way they influence each other. For example: Strong Work-life balance is a significant aspect for teacher's efficacy and satisfaction, which contributes to individuals learning. This helps to recruit and retain enhanced motivated teachers by giving them stronger command over their work lives and a greater sense of possession. In today's context, the requisite of work-life balance strategies is vital for every class of employed personnel. The human resource management's task is to consistently plan and implement policies that enable their work-force to balance amongst their personal and professional lives. This is inescapable to increase efficiency, retention, and employee satisfaction, which ultimately strengthens the employee commitment. "Work-life balance is essentially about choice and flexibility, balancing personal life and work, balancing the needs of both, the owner and the employees and the right environment for enhanced performance and satisfaction at all levels. Work-life Balance is not just concerning women's work, home and family juggling - though it is certainly a significant part of it, it is also about customizing work schemas and policies so that all irrespective of their age, race or gender can identify an accord that enables them to combine work with their other responsibilities or aspirations effortlessly. "Work-family balance" refers to the degree to which a person experiences a positive and harmonious relationship between work and family life. And it can be seen as a 
pivot that measures the time and energy apportionment between work, family life and the term "work-family balance", a metaphor to combat the historical assumption of work and family relationships. Work-life balance is always a concern for those interested in the quality of work life and its relevance to wider quality of life. In Europe, during the early days of industrial revolution, chief concern was, with the implications of child labor. During the recession and again in some parts of Europe, the concern is with unemployment and its repercussions. Therefore, women who aspire to succeed in their liability at home and at the work field, maintain harmony - the organization of both. Their lives become disciplined and commanded and they follow a synchronous track. They fabricate a great level of settlement and alignment between the two roles of woman. A similar view is given by Melody Hessing (1994) in "More Than Clockwork: Women's Time Management in their joint workload", a sociological view-point scrutinizes how women manage their lives to achieve several tasks. Hessing notes that "women who have both paid and domestic responsibilities essentially be successful, or they face reprimand or condemnation as mothers and / or employees."

\section{WORK ENVIRONMENT DURING PANDEMIC COVID-19 ERA}

Covid-19 started in late 2019 and got spread in India during the first quarter of 2020, the day Government of India announced the "Janata curfew" first and later the lockdown on the country's working, changed country's the work environment drastically overnight. Except for emergency services like Grocery and Medical, working throughout the offices across the country ceased with immediate effect. During the first lock down of 21 days most of the industries simply expected for the lockdown to get over but when it was further curtailed and appeared to be for an indefinite time period, most of the industries made employees start "work from home". That was the beginning of an absolutely new encounter for majority of the people, a new era of working has begun. It was arduous for people who were not tech savvy to use the technology and work efficiently from home. And here the role of the organizational support comes into the picture. When the boundaries between workplace and home dissolved, it became even more difficult to maintain work life balance or we can say a "Screen Life Balance". Here, evolvement of new technology and policies by the Human Resource Department of the organization, play a vital role in the efficiency of the employees in Covied-19 era.

\section{RESEARCH METHOD SAMPLING AND PROCEDURE}

A total of 246 employees from various industries in the Gwalior region were surveyed for expected support from company management to maintain their work life balance and their work life balance during the Covid-19 era. A sample size of 300 employees was selected and a questionnaire was sent through Google Forms to collect response from them, of which 254 samples responded, but unfortunately 8 questionnaires were not filled accurate. Therefore, the total and exact collected responses were only 246. The research is based on the responses of 246 employees from various industries around \& within Gwalior (MP). The responses to all 17 questions in the questionnaire were collected on a 5-point Likert scale, where - 1: Strongly Disagree, 2: - Disagree, 3:- Neutral, 4:- agree and 5:- strongly agree.

\subsection{Research Design}

Null Hypothesis $\left(\mathrm{HO}_{1}\right)$ : There is no significant relationship between work life balance and perceived organization support.

Alternate Hypothesis $\left(\mathrm{H1}_{1}\right)$ : There is no significant relationship between work life balance and perceived organization support. 


\subsection{Data Analysis and Interpretation}

$\mathrm{P}$ Value of $\mathrm{HO}_{1}$ and $\mathrm{H}_{1}$ is 0.619 which satisfy the alternate hypothesis means there is significant relationship between perceived organization support and work life balance. Values for the different questions in the model of Work Life Balance and Perceived Organizational Support received during this research are explained in the figure given below. For instance, for the question about "having enough time for the family", the mean value of the responses was 0.72 on the same time for the question for having the enough time for friends, the mean value of the responses was 0.69 which shows that a good number of people can manage their time for their family and friends but during the response of the third question when they were asked about having very little time for or care about family, majority of the people agree with it and the mean value was 0.91 in the similar manner when we talk about perceived organisational support then most of the people believe that there organization cares for them, so the mean value for the first question was 0.79 . After collecting the mean values of all 9 questions of work life balance and 8 questions of perceived organisation with different mean value, when the research calculates the aggregate correlation among perceived organization support and work life balance, the correlation is 0.619 as shown in the table below, which means that although the organisation takes care of the wellbeing of the employees but still maintaining the work life balance is a critical task for the employees and the activities of the organization cannot really help a lot of employees to maintain the work life balance specially in covid-19 era. But on the contrary we cannot even ignore the importance of perceived organisational support. The reason for lesser value in the correlation among work life balance and perceived organizational support may also be because of the different family circumstances $\&$ household environment for different employees.

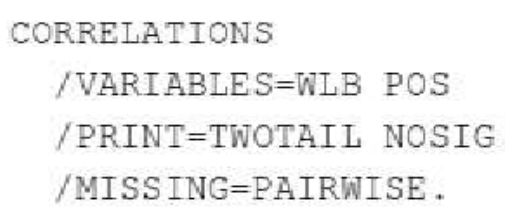

\section{Correlations}

[DataSet0]

Correlations

\begin{tabular}{|ll|r|r|}
\hline & & \multicolumn{1}{|c|}{ WLB } & \multicolumn{1}{c|}{ POS } \\
\hline WLB & Pearson Correlation & 1 & .619 \\
& Sig. (2-tailed) & & .102 \\
& N & 9 & 8 \\
\hline POS & Pearson Correlation & .619 & 1 \\
& Sig. (2-tailed) & .102 & \\
& N & 8 & 8 \\
\hline
\end{tabular}

NONPAR CORR

$/$ VARIABLES=WLB POS

$/$ PRINT=SPEARMAN TWOTAIL NOSIG

$/$ MISS ING=PAIRWISE . 


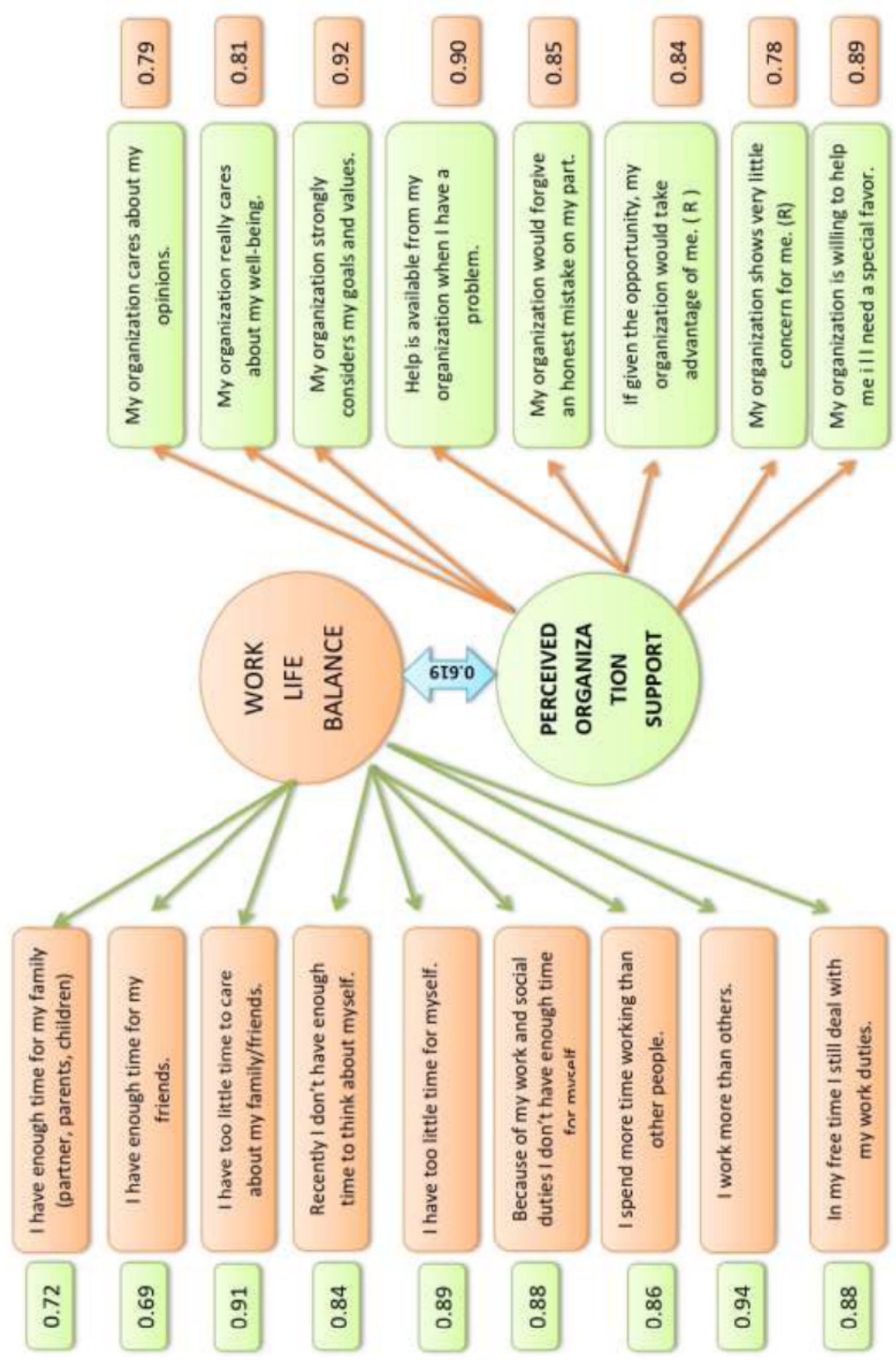

Figure 2 


\section{SCOPE \& LIMITATIONS OF THE STUDY}

It is very well known that the lockdown due to covid-19 was unexpected and duration was also not certain, hence, the policies of the Human Resource Department also kept changing from time to time. The responses may differ if the policies were unequivocal and bring implication on the employees for a distant future. The research will try to identify the correlation among perceived organisational support and work life balance in the normal course of working life.

\section{REFERENCES}

[1] Angle, H.L., \& Perry, J.L. (1983). Organizational commitment: Individual and organizational influences. Work and Occupations, 10, 123-146.

[2] Bentler, P. M. (1990). Comparative fit indices in structural equation modeling. Psychological Bulletin, 107, 238-246.

[3] Blau, E M. (1964). Exchange and power in social life. New York: Wiley.

[4] Browne, M.W., \& Cudeck, R. (1993). Alternative ways of assessing model fit. In K.A. Bollen \& J. S. Long (Eds.), Testing structural equation models (pp. 136-162). Newbury Park, CA: Sage.

[5] Cohen, J., \& Cohen, R (1983). Applied multiple regression/ correlation analysis for the behavioral sciences (2nd ed.). Hillsdale, NJ: Erlbaum. Cotterell, N., Eisenherger, R., \& Speicher, H. (1992).

[6] Inhibiting effects of reciprocation wariness on interpersonal relationships. Journal of Personality and Social Psychology, 62, 658-668.

[7] Dillman, D. A. (1978). Mail and telephone surveys: The total design method. New York: Wiley.

[8] Eisenberger, R., Cotterell, N., \& Marvel, J. (1987). Reciprocation ideology. Journal of Personality and Social Psychology, 53, 743-750.

[9] Eisenberger, R., Fasolo, E M., \& Davis-LaMastro, V. (1990). Effects of perceived organizational support on employee diligence, innovation, and commitment. Journal of Applied Psychology, 53, 51-59.

[10] Eisenberger, R., Huntington, R., Hutchison, S., \& Sowa, D. (1986). Perceived organizational support. Journal of Applied Psychology, 71, 500-507.

[11] Etzioni, A. ( 1961 ). A comparative analysis of complex organizations. New York: Free Press.

[12] Fasolo, R (1995). Procedural justice and perceived organizational support: Hypothesized effects on job performance. In R. Cropanzano \& K. M. Kacmar (Eds.), Organizational politics, justice, and support: Managing social climate at work (pp. 185-195). Westport, C'12. Quorum Press.

[13] George, J. M., Reed, T. E, Ballard, K. A., Colin, J., \& Fielding, J. (1993). Contact with AIDS patients as a source of workrelated distress: Effects of organizational and social support. Academy of Management Journal, 36, 157-171.

[14] Goranson, R. E., \& Berkowitz, L. (1966). Reciprocity and responsibility to prior help. Journal of Personality and Social Psychology, 3, 227-232. Gould, S. (1979). An equity-exchange model of organizational involvement. Academy of Management Review, 4, 53-62.

[15] Gouldner, A. W. (1960). The norm of reciprocity: A preliminary statement. American Sociological Review, 25, 161-178.

[16] Gross, A. E., \& Latane, J. G. (1974). Receiving help, reciprocation, and interpersonal attraction. Journal of Applied Social Psychology, 4, 210-223. 
[17] Guzzo, R. A., Noonan, K. A., \& Elron, E. (1994). Expatriate 820 Research Repokts managers and the psychological contract. Journal of Applied Psychology, 79, 617-626.

[18] James, L. R., Mulaik, S. S., \& Brett, J. M. (1982). Causal analysis: Assumptions, models, and data. Beverly Hills, CA: Sage.

[19] J Sreskog, K. G., \& Stirbom, D. (1993). LISREL 8: User's reference guide. Chicago: Scientific Software.

[20] Kiesler, S. B. (1966). The effect of perceived role requirements on reactions to favor doing. Journal of Experimental Social Psychology, 2, 198-210.

[21] Kirk, R. E. (1968). Experimental design: Procedures for the behavioral sciences. Belmont, CA: Brooks/Cole.

[22] Koys, D. J. (1991). Fairness, legal compliance, and organizational commitment. Employee Responsibilities and Rights Journal, 4, 283-291.

[23] Levinson, H. (1965). Reciprocation: The relationship between man and organization. Administrative Science Quarterly, 9, 370-390.

[24] March, J. G., \& Simon, H. A. (1958). Organizations. New York: Wiley.

[25] Marsh, H. W., Balla, J. R., \& McDonald, R. P. (1988). Goodness-of-fit in confirmatory factor analysis: The effect of sample size. Psychological Bulletin, 103, 391-411.

[26] Mowday, R.T., Porter, L.W., \& Steers, R.M. (1982). Employee-organizational linkages: The psychology of commitment, absenteeism, and turnover. New York: Academic Press.

[27] Nemeth, C. (1970). Effects of free versus constrained behavior on attraction between people. Jout'_nal of Personality and Social Psychology, 15, 302-311.

[28] Organ, D. W. (1988). A restatement of the satisfaction-performance hypothesis. Journal of Management, 14, 547-557.

[29] Quinn, R. P., \& Shepard, L. G. (1974). The 1972-1973 quality of employment survey. Ann Arbor: Institute for Social Research, University of Michigan.

[30] Rice, R. W., McFarlin, D. B., Hunt, R. G., \& Near, J. P. (1985). Job importance as a moderator of the relationship between job satisfaction and life satisfaction. Basic and Applied Social Psychology, 6, 297-316.

[31] Robinson, S. L., \& Morrison, E. W. (1995). Psychological contracts and OCB: The effect of unfulfilled obligations on civic virtue behavior. Journal of Organizational Behavior, 16, 289298.

[32] Rousseau, D. M. (1989). Psychological and implied contracts in organizations. Employee Rights and Responsibilities Journal 2, 121-139.

[33] Rousseau, D.M. (1990). New hire perceptions of their own and their employer's obligations: A study of psychological contracts. Journal of Organizational Behavior, 11, 389-400.

[34] Rousseau, D. M., \& Parks, J. M. (1993). The contracts of individuals and organizations. In L. L. Cummings \& B. M. Staw (Eds.), Research in organizational behavior (Vol. 15, pp. 1- 47). Greenwich, Cq2. JAI Press.

[35] Settoon, R. P., Bennett, N., \& Liden, R. C. (1996). Social exchange in organizations: Perceived organizational support, leader-member exchange, and employee reciprocity. Journal of Applied Psychology, 81, 219-227.

[36] Shore, L. M., \& Shore, T. H. (1995). Perceived organizational support and organizational justice. In R. Cropanzano \& K. M. Kacmar (Eds.), Organizational politics, justice, and support: Managing social climate at work (pp. 149-164). Westport, C1 . Quorum Press. 
[37] Shore, L. M., \& Tetrick, L. E. ( 1991 ). A construct validity study of the survey of perceived organizational support. Journal of Applied Psychology, 76, 637-643.

[38] Shore, L.M., \& Wayne, S.J. (1993). Commitment and employee behavior: Comparison of affective commitment and continuance commitment with perceived organizational support. Journal of Applied Psychology, 78, 774-780.

[39] Tucker, L. R., \& Lewis, C. (1973). A reliability coefficient for maximum likelihood factor analysis. Psychometrika, 38, 1- 10.

[40] Wayne, S. J., Shore, L. M., \& Liden, R. C. (1997). Perceived organizational support and leader-member exchange: A social exchange perspective. Academy of Management Journal, $40,82-111$.

[41] Widaman, K. E (1985). Hierarchically nested covariance structure models for multitraltmultimethod data. Applied Psychological Measurement, 9, 1-26.

[42] Witt, L. A. (1991). Exchange ideology as a moderator of job attitudes-organizational citizenship behaviors relationships. Journal of Applied Social Psychology, 21, 1490-1501. 